Magdalena Budzyńska-Łazarewicz

Uniwersytet im. Adama Mickiewicza w Poznaniu

\title{
„Królowa chaosu, niezrównoważona emocjonalnie, histeryczka trzaskająca drzwiami" - leksykalne sposoby wartościowania $w$ tekstach prasowych poświęconych Ewie Kopacz (na materiale wybranych tygodników opinii z września 2014 roku)
}

\section{Wstęp}

Zagadnienia związane z istotą wartości, ich podziałem, hierarchizacją oraz wyrażaniem od dawna stanowią przedmiot zainteresowań filozofów, w szczególności aksjologów, ale również przedstawicieli innych dziedzin nauki. W latach 70. XX wieku badania nad związkami wartości i języka rozpoczęli także lingwiści. Współcześnie wiele uwagi poświęca się analizie wartościowania w mediach [Bralczyk, Majkowska 2000; Majkowska 2001; Majkowska 2012; Buława 2014; Cegieła 2014], co zrozumiałe, ponieważ prasa, radio, telewizja oraz Internet nie tylko dostarczają informacji i komentują wydarzenia, ale także w pewien sposób kreują rzeczywistość, dokonują selekcji wiadomości oraz ich wartościowania. Porządkują świat, ustalają, czy może raczej narzucają, hierarchię wartości, wskazują na to, co jest istotne, a co nie. Mają tym samym ogromny wpływ na odbiorców, ponieważ modelują ich postawy względem życia i wartości, zachowanie oraz język [Bralczyk, Majkowska 2000]. Ten ostatni jest szczególnie ważny, ponieważ, jak pisze Jerzy Bartmiński [2003: 64-65], jest „narzędziem wartościowania, nosicielem wartości i informuje o wartościach". Fakt, iż teksty prasowe nie tylko opisują, ale także, a współcześnie może nawet przede wszystkim, oceniają rzeczywistość, sprawia, że stanowią bardzo dobry materiał badawczy, który umożliwia obserwację bogatego zasobu językowych środków wartościowania.

Niniejsza analiza wpisuje się w nurt badań nad językiem prasy, jednak może również stanowić przyczynek do wniosków na temat zależności między wartościami a światem polityki. Badania z tego obszaru prowadził m.in. Kazimierz Ożóg [2004], który obiektem swojego zainteresowania uczynił teksty 
wyborcze, uczeni skupieni wokół projektu mającego na celu analizę zmian pojmowania nazw wartości w Polsce w latach 1990-2000 [Bartmiński, red. 2006] oraz uczestnicy konferencji Wartości w świecie polityki, która odbyła się w 2010 roku na Wydziale Nauk Politycznych i Dziennikarstwa Uniwersytetu im. Adama Mickiewicza w Poznaniu ${ }^{1}$.

Celem niniejszego artykułu jest zaprezentowanie wybranych językowych środków wartościowania obecnych w tekstach publicystycznych i informacyjnych poświęconych wyborowi Ewy Kopacz na stanowisko premiera. Materiał do badań stanowią artykuły ukazujące się na łamach 8 tygodników opinii wydawanych w Polsce we wrześniu 2014 roku: „Polityka”, „Newsweek”, „Wprost”, „Przegląd”, „W Sieci”, „Do Rzeczy”, „Tygodnik Powszechny”, „Gazeta Polska". Na potrzeby niniejszej pracy analizie poddano 32 numery (po 4 z każdego tytułu). Sądy wartościujące pojawiały się przede wszystkim w artykułach publicystycznych, które ze swej natury nastawione są na ocenianie bieżących wydarzeń i zjawisk. W badanym materiale brałam pod uwagę także teksty informacyjne, ponieważ, jak wskazywała Jadwiga Puzynina [1984], również w nich obecne są wypowiedzi o charakterze wartościującym. Zakreślony przedział czasowy jest krótki, ale istotny pod względem liczby pojawiających się w prasie wypowiedzi, które oceniają i wartościują Ewę Kopacz, gdyż we wrześniu 2014 roku wszystkie wymienione periodyki poświęcały dużo uwagi objęciu przez nią stanowiska Prezesa Rady Ministrów.

W tym miejscu należy dodać, że wybrane tygodniki reprezentują różne poglądy społeczno-polityczne. „Polityka” jest pismem o profilu liberalno-lewicowym [Zuba 2012: 307-308]. ,,Wprost” to czasopismo, które na przestrzeni lat zmieniało profil ideowy. W książce Polska scena polityczna. Ciagłość i zmiana Krzysztof Zuba prezentuje wyniki analizy jego zawartości, wskazując, że w latach 1999-2011 „Wprost” propagował treści konserwatywne, przy czym od maja 2010 roku można było zaobserwować liberalizację pisma [Zuba 2012: 307-308], związaną z objęciem stanowiska redaktora naczelnego przez Tomasza Lisa. W okresie, którego dotyczą badane teksty, pismem kierował Sylwester Latkowski. Zasłynął on głównie z upublicznienia na łamach tygodnika dwóch afer: taśmowej (z politykami i biznesmenami w rolach głównych) oraz dotyczącej Kamila Durczoka, byłego już szefa „Faktów” TVN. W sytuacji spadającej popularności tygodnika „Wprost” oraz rosnącego zainteresowania kierowanym przez Lisa „Newsweekiem” konieczna była radykalizacja treści pisma oraz sięgnięcie po metody, które uczynią je bardziej atrakcyjnym. Redakcja „Przeglądu” charakteryzuje swoje poglądy jako centrowo-lewicowe i pro-

1 Pokłosiem tych obrad jest zbiór pokonferencyjny [zob. Miluska, red. 2012]. 
europejskie, deklaruje także, iż dziennikarze „stają w obronie demokratycznych norm, praw kobiet, mniejszości oraz przeciwstawiają się nietolerancji oraz ksenofobii” [O Przegladzie 2016]. Tygodniki „Do Rzeczy” oraz „W Sieci” prezentują profil konserwatywno-liberalny, natomiast „Gazeta Polska” - prawicowo-konserwatywny. „Tygodnik Powszechny” to pismo katolickie o tematyce społeczno-kulturalnej, które stara się godzić wartości liberalne z zasadami wiary, prezentuje ekumeniczny nurt polskiego katolicyzmu.

W kontekście rozważań nad językiem tekstów prasowych niezwykle istotna jest świadomość istnienia w mediach zjawiska tabloidyzacji, które wiąże się z przewagą opinii nad faktami [Pisarek 2008: 134] oraz z wszechobecnym wartościowaniem. Jedno z jej pierwszych ujęć zaproponował Howard Kurtz. Ten amerykański dziennikarz i badacz mediów wskazał trzy podstawowe wyznaczniki tabloidyzacji: powszechnie obserwowane pogorszenie się standardów dziennikarskich, zmniejszanie się liczby tzw. informacji twardych, dotyczących kwestii politycznych czy ekonomicznych, na rzecz informacji miękkich, służących niezbyt wysublimowanej rozrywce, wywoływaniu sensacji, skandalu, oraz „generalna zmiana (bądź poszerzenie) definiowania przez media tego, co ich zdaniem wyborca powinien wiedzieć, aby oceniać przydatność konkretnej osoby do funkcjonowania w życiu publicznym" [Piontek, Hordecki, Ossowski 2013: 12].

W przekazie tabloidalnym eksponowana jest przede wszystkim sensacyjność, emocjonalność relacji, brak natomiast głębszej refleksji nad faktami. Wartość merytoryczna informacji schodzi na dalszy plan, szczególnie w wypadku treści wymagających od nadawcy i odbiorcy wiedzy na jakiś temat [Majkowska, Satkiewicz 1999: 191]. Materiały ilustracyjne przeważają nad tekstem [Bugajski 2010: 66-67], który z kolei musi być na tyle atrakcyjny i chwytliwy, by przyciągać uwagę potencjalnych odbiorców ${ }^{2}$. Elementy, które do niedawna charakterystyczne były dla tzw. prasy brukowej, współcześnie przenikają także do mediów głównego nurtu. To, co „nietabloidowe”, upodabnia się do tego, co ,tabloidowe”, powstaje trzeci, hybrydyczny styl przekazywania informacji, a w efekcie - nowy typ kultury medialnej [Bauer 2010: 43-44].

Analiza tekstów dotyczących przejęcia władzy przez następczynię Donalda Tuska wymaga zarysowania kontekstu, w którym one powstały, i szerszego spojrzenia na sytuację społeczno-polityczną w ówczesnej Polsce. Charakteryzując obraz polskiego społeczeństwa na przełomie XX i XXI wieku, Maria Jarosz [red. 2013: 18] wskazuje na pogłębiającą się jego polaryzację,

2 Zjawisko tabloidyzacji może dotyczyć także innych obszarów. Mówi się o kulturze tabloidalnej, tabloidyzacji polityki, emocji [Piontek 2007: 236-237]. 
której efektem jest „,pęknięcie Polski na «solidarną i liberalną»” (wcześniej „akowską" i „postkomunistyczną”). Źródeł tej dychotomii redaktorka książki Polskie bieguny doszukuje się w ekonomicznych i politycznych aspektach transformacji państwa. W uproszczonym ujęciu opozycję tę ilustruje podział na elektoraty dwóch partii: zwolenników myślenia prawicowo-narodowego, jakie reprezentuje Prawo i Sprawiedliwość, oraz konserwatywno-neoliberalnego, utożsamianego z Platformą Obywatelską [Jarosz, red. 2013: 18]. Początkowo obie formacje uznawano za populistyczne i zwrócone przeciwko elitom. Momentem przełomowym okazał się rok 2005, gdy Polacy zagłosowali na koalicję PO-PiS, ale po wyborach wygranych przez PiS ujawniły się na tyle duże różnice, że do porozumienia nie doszło.

Uznaje się, że przemiany w PO i dojście tej partii do władzy w 2007 roku były efektem społecznej potrzeby zamknięcia czasu transformacyjnej traumy oraz odejścia od polaryzacji, jaka miała miejsce w trakcie dwuletniego kierowania państwem przez PiS [Smolar, Żukowski 2011]. Po zmianie rządu polityka nie skupiła się bardziej wokół centrum, a konflikty nie wygasły przeciwnie, przez ponad dwa lata Polacy obserwowali w mediach spór między prezydentem Lechem Kaczyńskim i rządem koalicji PO-PSL. Katastrofa smoleńska, do której doszło 10 kwietnia 2010 roku, pogłębiła tylko dotychczasowe podziały [Dudek 2013: 622].

Ostateczne przejęcie władzy wykonawczej w Polsce przez jedną z rywalizujących dotąd partii nastąpiło po zwycięstwie Bronisława Komorowskiego w przedterminowych wyborach prezydenckich w 2010 roku, a właściwie już podczas pełnienia przez niego obowiązków głowy państwa. W wyborach parlamentarnych w 2011 roku zwyciężyła PO, potwierdzając tym samym swoją dominację.

\section{Z gabinetu lekarskiego do wielkiej polityki - sylwetka Ewy Kopacz}

W opisywanym okresie znaczącą rolę w polskim życiu publicznym odegrała Ewa Kopacz. Z wykształcenia lekarz pediatra, swoją działalność polityczną rozpoczęła w latach 80. XX w. w Zjednoczonym Stronnictwie Ludowym. W latach 90. dołączyła natomiast do Unii Wolności, której strukturom przewodniczyła w ówczesnym województwie radomskim. W 1998 roku uzyskała w wyborach samorządowych mandat radnej sejmiku mazowieckiego. Trzy lata później stała się członkiem PO, a następnie posłem. W Sejmie zasiadała bez przerwy przez dekadę. W 2005 roku objęła stanowisko przewodniczącej Komisji Zdrowia, rok później także rzeczniczki ds. zdrowia w tzw. gabinecie cieni PO. Pełniła również obowiązki przewodniczącej partii w województwie mazowieckim. W 2007 roku Donald Tusk powierzył jej stanowisko ministra 
zdrowia. Piastując je, w 2009 roku sprzeciwiła się zakupowi przez polski rząd szczepionek przeciwko tzw. świńskiej grypie w okresie pandemii, którą ogłosiła Światowa Organizacja Zdrowia. Decyzja ta wzbudziła wiele kontrowersji - dla zwolenników Ewy Kopacz stanowiła dowód roztropności przyszłej pani premier, zaś przez jej oponentów uznawana była za skrajną nieodpowiedzialność i zaniedbanie.

W latach 2010-2014 Ewa Kopacz pełniła funkcję wiceprzewodniczącej oraz pierwszej wiceprzewodniczącej PO. 7 listopada 2011 roku została odwołana ze składu Rady Ministrów, a dzień później wybrana marszałkiem Sejmu. Była pierwszą kobietą w historii polskiego Sejmu na tym stanowisku. W związku z przewidywaną rezygnacją Donalda Tuska, który został przewodniczącym Rady Europejskiej, 3 września 2014 roku zarząd krajowy PO rekomendował jej kandydaturę na urząd premiera, dwanaście dni później prezydent Bronisław Komorowski mianował ją na stanowisko Prezesa Rady Ministrów.

W listopadzie 2014 roku Ewa Kopacz została przewodniczącą PO, natomiast w 2015 roku jednym z założycieli komitetu wyborczego Bronisława Komorowskiego w wyborach prezydenckich. W tym samym roku wystartowała w wyborach parlamentarnych jako lider listy wyborczej PO w okręgu warszawskim. Osiągnęła najwyższy indywidualny wynik w kraju, uzyskując mandat posłanki na Sejm VIII kadencji. 12 listopada 2015 roku złożyła dymisję. Tego samego dnia bezskutecznie kandydowała na stanowisko przewodniczącego klubu parlamentarnego PO. 16 listopada 2015 roku zakończyła urzędowanie na stanowisku Prezesa Rady Ministrów³.

\section{Językowe środki wyrażania sądów wartościujących}

Warto mieć na uwadze, że badacze różnorodnie definiują samo pojęcie wartościowania. Jadwiga Puzynina [2003: 27] uznaje, że jest to „(porównawcze lub przynajmniej bezpośrednio niezależne od porównań) uznawanie czegoś za (w jakimś stopniu i pod jakimś względem) dobre lub za (w jakimś stopniu i pod jakimś względem) złe”. Elżbieta Laskowska [1992: 20] ujmuje kwestię podobnie. Nazywa wartościowaniem ,przekonanie wartościujące lub inaczej sąd wartościujący polegający na przypisywaniu wartości jakiemuś przedmiotowi”. Wyznaczniki wartościowania, które pozwalają sprecyzować, ze względu na co przedmiot wartościowania należy uznać za dobry lub zły, przyjmuję za Puzyniną, wyróżniającą wartości transcendentne, poznawcze, estetyczne, moralne, obyczajowe, witalne i odczuciowe (w tym hedonistyczne). Listę tę poszerzam

3 Część artykułu poświęconą biografii Ewy Kopacz sporządzono na postawie informacji zawartych w analizowanych tekstach prasowych. 
jednak o wartości perfekcjonistyczne oraz utylitarne zaproponowane przez Laskowską [1996].

Środki wyrażania wartościowań pozytywnych i negatywnych można, za autorką Języka wartości, podzielić na dwie grupy ${ }^{4}$. Do pierwszej zaliczymy środki systemowe, skonwencjonalizowane, do drugiej natomiast - tekstowe, fakultatywne, zależne od kontekstu, zyskujące znaczenie wartościujące za sprawą konotacji, specyficznego zastosowania słów. Na tę klasyfikację należy nałożyć jeszcze podział na środki parajęzykowe, językowe oraz stylistyczne [Puzynina 1992: 111-130] . Środki systemowe pełnią funkcję wartościującą, ponieważ zawierają sem z informacją aksjologiczną. Wartościowanie jest tu zatem elementem definicyjnym formy wyrazowej, fleksyjnej, słowotwórczej, składniowej ${ }^{6}$. Analiza tych jednostek języka umożliwia poznanie modelu wartościowania charakterystycznego dla danej wspólnoty kulturowo-językowej.

W niniejszym artykule analizie poddaję przede wszystkim leksykę wartościującą, która stanowi przykład wartościowania systemowego. W kilku wypadkach pokazuję także egzemplifikacje dookreślania znaczenia leksemu oraz zmiany znaku wartości leksemu za sprawą kontekstu, w jakim się pojawia.

\section{Leksyka wartościująca $w$ analizowanych tekstach}

Puzynina wyróżnia dwie grupy leksemów wartościujących. Do pierwszej z nich zalicza wyrazy ogólnie wartościujące, czyli prymarnie nacechowane aksjologicznie, w których składnik oceniający jest obligatoryjny i należy do definicji leksemu, np. dobry, zły, dobro, zło, pozytywny, negatywny, właściwy, niewtaściwy, ujemny, dodatni. $\mathrm{W}$ analizowanym materiale leksemy prymarnie wartościujące są nielicznie reprezentowane. Te, które udało się wyekscerpować, służą przede wszystkim negatywnemu wartościowaniu zarówno samej Ewy Kopacz, jak i podejmowanych przez nią w przeszłości działań oraz sposobu, w jaki pełniła rozmaite funkcje. Są to wyrazy odwołujące się do grupy

4 Puzynina [1992: 111] wskazuje na niejednoznaczność podziału na środki systemowe oraz tekstowe i podkreśla, że „,nie mamy tu do czynienia z ostrą klasyfikacją, raczej z typologią, wyodrębnieniem dwóch zbiorów o rozmytych granicach".

5 Nieco inny sposób porządkowania środków wyrażających wartościowanie zaproponowała w swojej książce Monika Buława [2014]. Badaczka podzieliła analizowane wypowiedzi na trzy grupy: wypowiedzi ze środkami leksykalnymi wyrażającymi wartościowanie, wypowiedzi ze środkami pozaleksykalnymi w funkcji wartościującej oraz wypowiedzi wyrażające sąd wartościujący pragmatycznie.

6 Składnię (za Puzyniną) uznaję za przykład wartościowania systemowego, mając jednak świadomość, że w niektórych przypadkach wartościowanie związane jest z wypełnieniem leksykalnym konstrukcji zdaniowej, co sprawia, że można w tym wypadku mówić o wartościowaniu kontekstowym [por. Wrześniewska-Pietrzak 2012: 105]. 
wartości perfekcjonistycznych - przysłówki (źle, nieźle, fatalnie) oraz przymiotniki (zły, fatalny):

Ewa Kopacz zaczyna źle. [TP 39]

Kopacz jest $z ł a$ menedżerką, co udowodniła, kiedy była ministrem zdrowia. [WS 37]

$\mathrm{Na}$ dodatek fatalnie rozpoczyna się działalność premier Kopacz w ocenie badanych w sondażach. [GP 39: 13]

Ministrem zdrowia była fatalnym [...]. [DRZ 39: 10]

Ewa Kopacz jest typem „,menedżera ze scenariuszem”. Jako marszałek Sejmu radziła sobie zupełnie nieźle [...]. [WS 40: 24]

Obecny w pierwszym przykładzie zwrot zaczynać źle może stanowić nawiązanie do sformułowania (ktoś) źle skończyt - 'poniósł klęskę, doznał

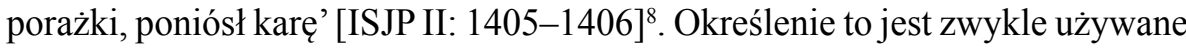
w odniesieniu do osoby, która zakończyła życie. Wymiana jednego członu tego połączenia, zastąpienie czasownika dokonanego skończyć niedokonanym zaczynać sprawia, że w negatywny sposób oceniane są działania dopiero planowane, których ewentualne pozytywne lub negatywne następstwa mogą jeszcze nie być widoczne. Przymiotnik zły odnosi się do konkretnej umiejętności podejmowania decyzji i zarządzania, jaką będzie musiała się wykazać premier Ewa Kopacz i której, zdaniem autora artykułu, już kiedyś jej zabrakło. Ta negatywna ocena wyrażana jest w jeszcze bardziej intensywny sposób przymiotnikiem fatalny i przysłówkiem fatalnie, wskazującymi na to, że pełniąc funkcję ministra zdrowia, przyszła premier nie sprawdziła się.

W ostatnim przykładzie pojawia się natomiast jedyny spośród wymienionych w tej grupie leksem prymarnie wartościujący, który służy pozytywnej waloryzacji pewnego etapu w karierze Kopacz. Nieźle to jednak zaledwie dość dobrze, zatem i ten wyraz nie ociepla zbytnio wizerunku opisywanej osoby.

Drugi zbiór stanowią wyrazy opisowo-wartościujące, które, podobnie jak prymarne, odnoszą się do jakiegoś fragmentu rzeczywistości i jednocześnie

7 Cytaty z tygodników oznaczam, podając w nawiasie kwadratowym w następującej kolejności: skrót tytułu (zob. Spis skrótów), numer tygodnika i po dwukropku numer strony. Wyróżnienia w przykładach pochodzą od autorki.

8 W przypisach do cytatów z Innego słownika języka polskiego podaje się każdorazowo skrót ISJP, następnie numer tomu i po dwukropku numery stron. 
wartościują, ale, co istotne, ogarniają ,,swoją treścią element czy też elementy semantyczne, ze względu na które wyraz jest nacechowany pozytywnie lub negatywnie" [Puzynina 2004: 185]. Komponent oceny może stanowić definicyjną lub konotacyjną ${ }^{9}$ część struktury takiego leksemu [Buława 2014: 49]. W analizowanych tekstach pojawiają się także nieliczne jednostki nacechowane emocjonalnie, a zatem takie, które wyrażają wartościowanie według kryterium etycznego czy poznawczego, a także odczuciowego. Są to zwykle elementy językowe negatywnie wartościujące, np.:

Kiedy w TVN, podczas dyskusji, zwróciłem uwagę na kłamstwa minister Kopacz, wywołałem zniesmaczenie pozostałych jej uczestników. Nikt nie mógł zaprzeczyć faktom, za skandaliczne jednak uznali oni nie kłamstwa pani minister, ale nazwanie ich po imieniu. [DRZ 39: 10]

Przypomnijmy raz jeszcze - należy robić to do upadłego - że publicznie z mównicy sejmowej, oktamała Polaków w sprawie tak poważnej jak tragedia smoleńska. [DRZ 39: 10]

Powtarzane wielokrotnie w odniesieniu do Ewy Kopacz rzeczownik kłamstwo i czasownik ktamać, stanowiące centrum pojęciowe negatywnych wartości poznawczych, wskazują na to, że pani premier podawała do publicznej wiadomości informacje niezgodne z rzeczywistością, przekazywała je w celu wprowadzenia w błąd, zmylenia [ISJP I: 631].

W cytowanych wypowiedziach pojawiają się także dodatkowe środki służące ocenie - referowane jest wartościowanie innych osób (,[...] za skandaliczne jednak uznali oni nie kłamstwa pani minister, ale nazwanie ich po imieniu”), występuje „my” inkluzywne („Przypomnijmy raz jeszcze [...]”), a także frazeologizm (robić coś do upadtego).

Wartościowanie może się ujawniać w jednostkach leksykalnych nazywających pewne cechy, właściwości, np. w przymiotnikach i przysłówkach. W tego typu przykładach wartościowany jest obiekt, któremu nadawca przypisuje tę cechę. $\mathrm{Z}$ analizowanych tekstów udało się wyekscerpować wiele fragmentów, w których pojawiają się elementy językowe odnoszące się do konkretnych cech Ewy Kopacz, np.:

9 Konotację rozumiem za Buławą [2014: 49] jako „niedefinicyjne, aktualizowane kontekstowo elementy znaczenia leksykalnego, które przeciwstawić można elementom desygnacyjnym stanowiącym konieczny składnik każdego użycia wyrazu i wystarczającym do odróżnienia jego znaczenia od znaczeń innych jednostek”. 
Ewa Kopacz jest odważna, wyrazista, ma w partii zwolenników, ale ma także przeciwników. [P 36: 12]

Marszałek Kopacz wydaje się jego [Grzegorza Schetyny - M.B.Ł.] przeciwieństwem - przede wszystkim jest absolutnie lojalna wobec rządu, a już zwłaszcza premiera [...]. [PO 37: 12]

Jak skuteczna potrafi być Ewa Kopacz, odczuł na własnej skórze mecenas Borysław Szlanta, szef radomskiej kampanii wyborczej UW. [WS 37: 20]

Przywołane przykłady wskazują na cechy odnoszące się nie tylko do różnych sfer działalności pani premier, ale także jej charakteru, a tym samym do kilku grup wartości. Przymiotniki odważny i wyrazisty, występujące w pierwszym cytacie, nawiązują do kryterium poznawczego. Nazywają jednostkę, która gotowa jest robić rzeczy niebezpieczne i nie boi się trudnych sytuacji [ISJP I: 1132], oraz kogoś, kto przekazuje jakieś treści w wyraźny sposób, posiada cechy łatwe do zdefiniowania lub odróżnienia [ISJP II: 1138]. Obecnemu w drugim zdaniu przymiotnikowi pozytywnie wartościującemu lojalny, który odsyła z kolei do kryterium moralnego, towarzyszą także inne środki intensyfikujące wartościowanie: partykuła przede wszystkim [Kisiel 2009], przysłówek absolutnie oraz modulant sytuujący zwłaszcza. W tygodniku „W Sieci” pojawił się natomiast przymiotnik skuteczny w znaczeniu 'dający oczekiwane wyniki, wywołujący pozytywny skutek’ [ISJP II: 613]. Autor artykułu posłużył się nim ironicznie, przypominając historię spektakularnego przejęcia przez Ewę Kopacz władzy w wojewódzkich strukturach Unii Wolności.

W badanym materiale nie brakuje także wypowiedzi, w których przyszła premier jest oceniana negatywnie:

Wspinając się po szczeblach politycznej kariery, wielokrotnie pokazała, że potrafi być tak samo bezwzględna, jak Donald Tusk. [DRZ 37: 25]

Była groźna kiedy na partyjnych naradach jako pierwsza atakowała konkretnych polityków, bo doskonale wiedziano, kto jej ustami wskazuje sprawców „rozbijackiej roboty w partii” [...]. [DRZ 39: 32]

Pierwszy z powyższych cytatów stanowi przykład zdania, w którym przymiotnik jest częścią konstrukcji komunikującej wartościowanie porównawcze. Wyraz bezwzględny wartościuje tu negatywnie zarówno Ewę Kopacz, jak 
i Donalda Tuska. Odsyła do kryterium poznawczego i odnosi się do kogoś, kto jest bardzo surowy wobec innych, czasem nawet okrutny [ISJP I: 89]. Negatywne zabarwienie ma także leksem groźny. Określa on kogoś lub coś, co zagraża, budzi niepokój, obawy [ISJP I: 482]. Wartościowaniu służą w analizowanych tekstach również przymiotniki w formie zaprzeczonej, które wskazują na cechy pejoratywne Ewy Kopacz:

$\mathrm{Z}$ niedoświadczonq $\mathrm{w}$ naprawdę brutalnej polityce lekarką z Szydłowca prezydentowi poszło łatwo. Ze starymi partyjnymi wygami może być znacznie trudniej. [DRZ 40: 24]

Kandydaci na następców, z Ewą Kopacz i Elżbietą Bieńkowską na czele, to osoby zupełnie niesamodzielne. [WS 37/14: 3]

Kopacz jest przy tym osobą wybitnie niestabilnq emocjonalnie. To też jej nie pomoże, bo zapewne uczyni niedostatki intelektualno-polityczne bardziej widocznymi. [WS 37: 24]

Prezentacja rządu na Politechnice unaocznia jeszcze jeden niebłahy problem nowej szefowej rządu. [WS 40: 23]

Wskazane przymiotniki odwołują się do kryterium utylitarnego i perfekcjonistycznego. Określają ówczesną marszałek sejmu jako kogoś niemającego wprawy w rządzeniu, niepotrafiącego samodzielnie funkcjonować, nieustannie korzystającego z czyjejś pomocy, wreszcie kogoś, kto nie decyduje o sobie, gdyż podlega innej osobie lub instytucji [ISJP I: 1011-1012]. Autor artykułu opublikowanego w tygodniku „W Sieci” posługuje się przymiotnikiem zaprzeczonym, nazywa przyszłą premier niestabilna, wskazuje na jej skłonność do nagłej zmiany zdania, która powoduje chaos organizacyjny [ISJP I: 1014-1015]. Jest to jednak niestabilność emocjonalna, zatem diagnozowane w sposób nieformalny swego rodzaju zaburzenie osobowości.

Analiza materiału prasowego wykazała, że występujące w tekstach przymiotniki i imiesłowy służą także wartościowaniu konkretnych zachowań Ewy Kopacz oraz podejmowanych przez nią działań:

Pani premier mogła sobie jednak pozwolić nawet na dziwaczne uwagi o kobiecości, zamiast odpowiedzieć na proste w końcu pytanie o broń dla Ukrainy. [DRZ 39: 30] 
W wielu wypowiedziach dla dziennikarzy w Sejmie łatwo przejawiała zgryźliwa ironię lub irytację z powodu stawianych przez nich pytań. [DRZ 37: 24]

Pierwszy fragment odnosi się do konkretnej sytuacji, w której premier pozwoliła sobie na dziwaczne, a zatem nieuzasadnione, nieodpowiednie w takim momencie wypowiedzi [ISJP I: 361]. Drugi wykorzystuje w celu wartościowania przymiotnik zgryźliwy, określający osobę dokuczającą innym, złośliwą [ISJP II: 1340]. Wskazuje ponadto na wielokrotnie powtarzające się zachowanie, które autor tekstu uznaje za charakterystyczne dla niej.

$\mathrm{W}$ analizowanym materiale pojawiają się także wypowiedzi, w których występują przymiotniki w stopniu wyższym i najwyższym, przy czym te drugie są zdecydowanie bardziej licznie reprezentowane. Zarówno comparativus, jak i superlativus służą wyrażaniu wartościowania porównawczego. Roman Laskowski pisał, że wskazują one, iż jednemu, wyróżnionemu w ten sposób obiektowi określona właściwość czy cecha przysługuje w stopniu wyższym niż innym elementom tego zbioru. W wypadku przymiotnika lub przysłówka w stopniu wyższym otrzymujemy informację o tym, że jest to zbiór dwuelementowy, w sytuacji, gdy jest to superlativus, zbiór ma więcej niż dwa elementy [Laskowski 1977: 325]. W analizowanych tygodnikach opinii wartościowaniu służyły przymiotniki stopniowane zarówno w sposób prosty, jak i opisowy. Tych pierwszych jest jednak zdecydowanie więcej:

To oczywiste, że na pytanie o wojnę na Ukrainie absolutnie nic glupszego niż wypowiedź szefowej polskiego rządu nie można wymyślić. [GP 39: 2]

Trudno było wyobrazić sobie Radę Ministrów konstruowaną w bardziej nieporadny sposób, niż zrobiła to Ewa Kopacz. [DRZ 39: 31]

A najstraszniejsze jest to, że większość ofiar [,,świńskiej grypy” w Polsce M.B.Ł.] mogłaby żyć do dzisiaj, gdyby nie decyzje minister Ewy Kopacz. [GP 39: 4]

Przywołane przykłady pokazują, że ocenie podlegały różne aspekty działalności nowej premier: wystąpienia publiczne, podejmowane decyzje, sposób zarządzania kierowaną przez nią jednostką, reprezentowanie interesów Polski na arenie międzynarodowej. Wśród przymiotników negatywnie wartościujących pojawiły się m.in. leksemy: glupi, nieporadny, straszny. Informują one o tym, w jaki sposób autor artykułu postrzega konkretne epizody z politycznego życia Kopacz. 
Przymiotnik głupi odwołuje się do kryterium poznawczego i wartościuje negatywnie. Wykorzystując go w swojej wypowiedzi, autor podaje w wątpliwość zdolności intelektualne polskiej premier, zarzuca jej bezmyślność. Podobny wydźwięk ma wyraz nieporadny, który wskazuje na brak umiejętności lub wprawy w wykonywaniu powierzonego zadania [ISJP I: 1003]. Leksem straszny służy natomiast podkreśleniu natężenia lub rozmiaru jakiegoś zjawiska, szczególnie negatywnego [ISJP II: 698]. W analizowanym materiale pojawił się on w wypowiedzi dotyczącej zlekceważenia przez Ministerstwo Zdrowia epidemii ,świńskiej grypy”.

Należy podkreślić, że w wyekscerpowanym zbiorze bardzo rzadko pojawiają się przymiotniki w stopniu wyższym lub najwyższym, które wartościują pozytywnie, np.

Można namalować kilka różnych portretów Ewy Kopacz. Najsympatyczniejszy i najmniej kontrowersyjny jest ten kobiecy, a zwłaszcza z okresu młodości. [PO 36: 10]

Wtedy Kopacz była już jedną z najważniejszych osób przy boku Tuska. [W 37: 13]

W pierwszym fragmencie użyto formy stopnia najwyższego przymiotnika sympatyczny oraz stopniowanego w sposób opisowy leksemu kontrowersyjny, mającego pierwotnie znaczenie negatywnie wartościujące. Towarzyszy mu przysłówek mało, za sprawą którego połączenie to zyskuje dodatni znak wartości. W drugim przykładzie mamy do czynienia z konstrukcją jeden z ..., która została uzupełniona formą stopnia najwyższego przymiotnika ważny. Kopacz jest przedstawiana jako osoba mająca duże możliwości wpływania na coś lub na kogoś dzięki zajmowanemu przez siebie stanowisku [ISJP II: 972].

Kontekstowo wartościują także obecne w poniższych przykładach leksemy najbardziej i najwięcej:

Najbardziej trywialnym problemem marszałkini Kopacz jest to, że bywa po prostu niesympatyczna. [DRZ 37: 24]

Najwięcej kontrowersji budzi działalność Ewy Kopacz jako ministra zdrowia. [PO 37: 12]

Wprowadzają one wartościowanie negatywne, intensyfikują znaczenie elementów językowych pojawiających się w sąsiedztwie: przymiotnika trywialny, 
wskazującego na coś mało wyszukanego, oczywistego [ISJP II: 856], oraz zwrotu budzić kontrowersje, który odnosi się sytuacji wywołującej sprzeczne opinie [ISJP I: 675]

Wartościowaniu służą także pojawiające się w tekstach prasowych zaimki przeczące (nic, nigdy, żaden) oraz upowszechniające (każdy, wszystko). Te należące do pierwszej grupy sygnalizują nieistnienie danej osoby, obiektu, zjawiska, zastępują zatem szczegółowe wskazania obiektów kwalifikowanych jako nieistniejące w danym miejscu i czasie [Szczepankowska 2012]. Służą ostrej krytyce premier Ewy Kopacz i podejmowanych przez nią działań. Odwołują się przede wszystkim do kryterium perfekcjonistycznego oraz poznawczego:

Nie spełniła niczego z tego, co obiecała - w tej kwestii niewiele różniła się od swoich kolegów - ale jej następca Arłukowicz musiał przyznać, że pozostawione przez nią projekty ustaw nie nadają się do niczego. [DRZ 39: 10]

Nie potrafiła powiedzieć niczego o programie rządu ani wymienić tego, co jest priorytetem. [TP 39: 27]

Problem ludzi uzależnionych od rządów PO polega na tym, że chcą owego przywódcę widzieć w osobie, która nigdy przypisywanymi jej cechami się nie wykazała, a jej pierwsze medialne występy wskazują raczej na zagubienie i skłonność do kompromitujących wpadek. [DRZ 40: 32]

[Ewa Kopacz - M.B.Ł.] nie ma nic do powiedzenia w sensie ideowym. Żadnych własnych propozycji. [N 38: 14]

Zdania, w których pojawiają się zaimki upowszechniające, nie pozostawiają odbiorcy wątpliwości co do niektórych opinii:

Niemal z każdego wypowiedzianego przez nią słowa i z większości jej gestów emanowały poczucie niepewności, nerwowość i obawa przed sformułowaniem jakiegokolwiek poglądu. [WS 40: 23]

Jako marszałek robiła wszystko, aby Sejm, który z zasady ma być miejscem debaty i zderzenia racji, zredukować do roli atrapy i maszynki do głosowania. Współdziałała więc w niszczeniu polskiej demokracji. [DRZ 39: 10]

W pierwszym z zacytowanych fragmentów określenia upowszechniające łączą się z rzeczownikami, które nazywają stany emocjonalne. Odnoszą się 
one do słabości opisywanej osoby: niepewność, nerwowość, obawa. Ciekawy wydaje się także drugi przykład. Zaimkowi wszystko towarzyszy tutaj kilka innych elementów językowych, które intensyfikują wartościowanie. Autor artykułu negatywnie ocenia działania premier Ewy Kopacz. Posługuje się rzeczownikiem odczasownikowym niszczenie, przypisuje pani premier intencję rujnowania polskiego ustroju politycznego. Cel jej działań nazwany został za pomocą negatywnie wartościujących mechanizmów: zredukować, atrapa, maszynka do głosowania. Odnoszą się one do wizerunku sejmu, jaki w opinii autora artykułu buduje premier rządu. Określenia te stanowią antynomię założenia modelowego, w którym parlament jest „,miejscem debaty i zderzenia racji”. Sugerują, że sprawując obowiązki marszałka, przyszła premier nie wywiązywała się z nich należycie. Autor artykułu zarzuca jej tworzenie fikcji, konstruowanie atrapy, a zatem czegoś, co udaje, że jest czymś innym, niż jest [ISJP I: 50].

W analizowanym materiale pojawiają się fragmenty, w których nadawca cytuje lub referuje stwierdzenia wartościujące. Zdania tego typu przekazują wiedzę na temat obiektu bądź zdarzenia, które jest przedmiotem wypowiedzi, ale mogą także wyrażać w zawoalowany sposób stanowisko nadawcy, jego osobiste wartościowanie [Błachut 2014; Buława 2014: 187]. Wprowadzaniu treści opisowych lub wartościujących służą verba dicendi:

I wbrew temu, co glosza jej krytycy, obecnej pozycji nie zawdzięcza wyłącznie niewzruszonej lojalności wobec premiera Tuska. [N 37: 16]

Politycy i publicyści prawicy już mówiq, że Kopacz była „główną macherką”, jeśli chodziło o prywatyzację szpitali i że brała udział w „kłamstwie smoleńskim", zapewniając w Sejmie, że ziemia na miejscu katastrofy została przekopana na metr w głąb. [N 37: 20]

Ta historia dobrze oddaje to, co jej koledzy z partii - zarówno byli, jak i obecni - nazywaja ,niestabilnością emocjonalną”. [DRZ 37: 26]

Mazowieccy samorządowcy do dziś opowiadaja o tym, jak w połowie lat 90. energiczna, sprawna i zaangażowana lekarka chciała zostać kierownikiem gminnego ośrodka zdrowia. [DRZ 37: 26]

Krytycy twierdza, że Ewa Kopacz całkowicie rozczarowała, choć nie wiadomo właściwie, czego się spodziewano i gdzie nowa premier popełniła te poważne błędy. [PO 39: 14] 
Często pojawiają się także jednostki informujące o reakcji emocjonalnej podmiotu, który dokonuje oceny, oraz nazywające czynności motywowane przez sądy wartościujące [Buława 2014: 188]:

Prawie wszystkie nasze rozmówczynie, „,byłe koleżanki” potwierdzaja jedno, że Ewa Kopacz była naprawdę niezłym pediatrą. [WS 37: 21]

Nawet sprzyjające jej media maja klopoty z określeniem tego okresu mianem sukcesu pani marszałek. [WS 37: 24]

Nawet bardziej trzeźwi publicyści z klubu kibiców PO maja watpliwości co do Ewy Kopacz. [DRZ 37: 24]

Nawet najzagorzalsi zwolennicy tej partii nie podkreślaja zdolności Ewy Kopacz do budowania samodzielnej pozycji, choćby na poziomie Elżbiety Bieńkowskiej. [TP 37: 23]

Królowa chaosu, niezrównoważona emocjonalnie, histeryczka trzaskająca drzwiami (premierowi), krzycząca, że herbata za mało słodka (to do sekretarki), bez pomysłów, ale z tupetem, a jednocześnie ktoś, komu wolno więcej niż innym, bo cieszy się poparciem i zaufaniem Donalda Tuska - takie opinie krąza dość powszechnie. [PO 37: 11]

Sporo wskazuje natomiast na to, że Ewa Kopacz potrafi skutecznie walczyć o władzę i wpływy. [TP 39: 22]

Zdarza się, że osoba oceniająca Ewę Kopacz jest konkretna, jednoznacznie wskazana przez dziennikarza, czasem ironicznie określona i poprzez to w pewien sposób wartościowana (byłe koleżanki, sprzyjające jej [Ewie Kopacz - M.B.Ł.] media, bardziej trzeźwi publicyści z klubu kibiców PO, najzagorzalsi zwolennicy tej partii [PO - M.B.Ł.]); najczęściej bywa jednak niedookreślona (sporo wskazuje) albo w ogóle nie jest zasygnalizowana (opinie krąża).

Trzy z zacytowanych powyżej zdań zbudowane zostały na tym samym schemacie, w którym modulant afektujący nawet akcentuje fakt, iż wątpliwości co do kandydatury Ewy Kopacz mają także osoby, które należą do tego samego środowiska politycznego, a więc choćby częściowo podzielają jej poglądy. Inne wartościują pozytywnie, odwołując się do kryterium perfekcjonistycznego. W pierwszym zdaniu mamy jednak do czynienia z oceną stanu z przeszłości 
(„Ewa Kopacz była naprawdę niezłym pediatrą"). Użycie takiej formy czasownika może oznaczać, że obecnie nie jest już w ten sposób postrzegana. W ostatnim zdaniu formuła sporo wskazuje wprowadza sąd: „Ewa Kopacz potrafi skutecznie walczyć o władzę i wpływy”, który odsyła do kryterium utylitarnego i perfekcjonistycznego.

Autorzy artykułów posługują się bardzo często bezosobowymi formami czasowników, utworzonymi poprzez dodanie zaimka zwrotnego się. Tego typu struktury mają wyrażać powszechność czynności wyrażonej czasownikiem:

Z lubością wypomina się jej chaotyczne rządy w resorcie zdrowia (złośliwi mawiali, że ona wprowadza zamieszanie, a pożary gasi jej zastępca Jakub Szulc), a także nieszczęśliwe wypowiedzi w Sejmie po katastrofie smoleńskiej. [TP 37: 20]

Po tym, jak ówczesna minister zdrowia publicznie deklarowała, że smoleńska ziemia była ,przekopana na metr”, w Szydłowcu nie mówi się o niej inaczej niż „Fadroma” - od nazwy wrocławskiej firmy produkującej specjalistyczne ładowarki kopalniane. [WS 37: 21]

A o Ewie Kopacz powiedziano natychmiast: niesamodzielna, bez charyzmy, marionetka Tuska, kierowana z tylnego siedzenia, żołnierz i ochroniarz premiera. [PO 37: 10]

Do znudzenia powtarza się, że rządem będzie tak naprawdę kierował z tylnego siedzenia Donald Tusk, a Kopacz jest zaledwie jego wierną protegowaną [...]. [TP 39: 22]

Komentarze prasowe koncentrują się przede wszystkim na poddawaniu krytyce dokonań Ewy Kopacz, wytykaniu jej potknięć, porażek, przypominaniu błędów i niedociągnięć. Ilustrują to dwa pierwsze z przywołanych powyżej przykładów, w których dziennikarz referuje stanowisko niesprecyzowanej grupy osób (w drugim fragmencie krąg ten został zawężony do mieszkańców Szydłowca, ale również nie wiadomo, o kim dokładnie mowa).

W podobnym tonie projektowana jest wizja politycznej przyszłości następczyni Donalda Tuska. Zastosowanie formy bezosobowej sugeruje, że dla autora artykułu nie ma znaczenia, z czyich ust padły konkretne stwierdzenia. W trzecim z zacytowanych fragmentów Ewa Kopacz została scharakteryzowana jako „niesamodzielna, bez charyzmy, marionetka Tuska”, a zatem ktoś słaby, ubezwłasnowolniony. W tej samej wypowiedzi pojawiają się jednak określenia 
„,̇̇łnierz i ochroniarz premiera”, wskazujące, że jest postrzegana jako osoba silna, odważna, aktywna. O rzekomym podporządkowaniu przyszłej premier obecnemu przewodniczącemu Rady Europejskiej mówi się także w sposób niedosłowny. Znamienne jest powtarzanie przez publicystów zwrotu, który funkcjonuje w polskich mediach już od dawna. Mowa o sformułowaniu kierować z tylnego siedzenia - 'wpływać na ważne decyzje polityczne rządu, nie mając ku temu stosownych uprawnień, w sposób niejawny, nieformalnie' [Smółkowa, red. 2013: 23]. Odbiorca po raz kolejny otrzymuje komunikat negatywnie wartościujący premier rządu i określający ją jako osobę, która nie ma mocy sprawczej, nie podejmuje samodzielnie żadnych decyzji, nie ponosi za nie odpowiedzialności.

Autorzy tekstów prasowych poświęconych Ewie Kopacz stosują także tzw. „my” inkluzywne. Angażują w ten sposób odbiorcę w akt wartościowania:

Gdy w telewizji obserwujemy kroczącą po sejmowych korytarzach Ewę Kopacz albo Ewę Kopacz zasiadającą w fotelu marszałka, widzimy polityka zdecydowanego i pewnego siebie. Jakiego polityka zobaczymy, gdy na trybunę sejmową wejdzie premier Kopacz? [N 38: 2]

Ewa Kopacz - jak pamiętamy - zapewniała, że miejsce tragedii zostało dokładnie sprawdzone i przekopane w poszukiwaniu szczątków ludzkich, gwarantowała też prawidłowy przebieg identyfikacji. [TP 37: 20]

Pierwszy przykład dowodzi, jak różnie była w analizowanych tekstach postrzegana desygnowana Prezes Rady Ministrów. W przywoływanych wcześniej fragmentach przeważał obraz słabej, niestabilnej emocjonalnie i nieprzyjaznej otoczeniu kobiety, „Newsweek” wskazuje natomiast na inne cechy jej charakteru: pewność siebie i zdecydowanie. W drugim przykładzie „my” inkluzywne zostało wprowadzone w celu zaznaczenia kilku istotnych kwestii. Nadawca oraz czytelnicy, których angażuje on w swoją wypowiedź, pamiętaja, mają świadomość, że Kopacz gwarantowała i zapewniała, a zatem przekazywała istotne informacje na temat badania miejsca katastrofy smoleńskiej, utwierdzając opinię publiczną w przekonaniu, że z całą pewnością są prawdą. W sytuacji, gdy po pewnym czasie na jaw wyszło wiele nieprawidłowości związanych z przebiegiem śledztwa, słowa te uznane zostały za kłamstwo z premedytacją. Zarzut rozmijania się z prawdą pojawiał się już wielokrotnie, na co wskazywano już we wcześniejszych fragmentach niniejszej pracy.

W niektórych artykułach występuje jednoznaczna informacja o tym, kto dokonał wartościowania. W celu przekazania takiej wiedzy nadawca posługiwał się zarówno mową zależną, jak i niezależną: 
To „stanowcza, charakterna, czasem histeryczna kobita” - pisat o niej Janusz Palikot w książce „Kulisy Platformy”. [N 37: 20]

- W wojnach wewnętrznych, intrygach i zdobywaniu kolejnych szczebli kariery jest bardzo sprawna. W budowaniu drużyny, pracy zespołowej, już nie. Choć musi mieć w sobie pewną dozę wrażliwości, w końcu jest lekarzem pediatrą. Myślę, że stąd bierze się jej emocjonalność - mówi Marek Suski. [DRZ 37: 26]

Rafał Grupiński wprost wskazywał, że nie wszyscy w Platformie wierzą, iż Ewa Kopacz przyniesie partii sukces. [DRZ 37: 23]

Wyrażaniu sądów wartościujących służą w analizowanych tekstach także wykładniki modalności, która we współczesnych pracach lingwistycznych postrzegana jest jako kategoria semantyczno-gramatyczno-pragmatyczna [Jędrzejko 2000: 125, 136-138]. Stanowi konstytutywny element wypowiedzenia współistniejący w każdym zdaniu wraz z predykacją [Łapa 2006: 7-10]. W badaniach nad związkami modalności i wartościowania szczególne znaczenie ma służąca wskazywaniu norm i wyrażaniu ocen modalność deontyczna [Ożdżyński 1999].

W książce Wartościowanie w języku potocznym Laskowska [1992: 131] wskazuje, że wypowiedziom powinnościowym, które są motywowane sądem wartościującym, można przyporządkować formułę „bo to dobre/złe” lub zbliżoną, w której pojawiają się inne przymiotniki sygnalizujące aspekt wartościowania. Według Jadwigi Puzyniny jest to niewystarczająca interpretacja. Badaczka wskazuje na konieczność orzekania powinności poprzez jednoczesne zastosowanie obu tych członów [Puzynina 1992: 88-89]. W analizowanych tekstach pojawiły się np. wyrażające nakaz konstrukcje z czasownikiem modalnym musieć:

[...] Ewa Kopacz musi więc zdecydować, czy będzie przedłużała politykę wycinania przeciwników zgodną z hasłem poprzednika: „Platforma musi być jak pięść", czy też postara się, by PO wróciła do korzeni: była formacją zróżnicowaną, a przez to ciekawszą, być może także dla wyborców. [TP 38: 5]

Żeby się uporać ze spadającymi na nią niedokończonymi pracami poprzednika, będzie się też musiała wykazać niezwykłą gibkością. [PO 38: 17]

Tak czy owak w sprawach bezpieczeństwa Ewa Kopacz i Bronisław Komorowski muszą teraz działać ręka w rękę. [N 38: 2] 
W pierwszym cytacie czasownik modalny wystąpił dwukrotnie: jako element dyrektywy sformułowanej przez autora artykułu oraz jako integralna część hasła opartego na porównaniu „Platforma musi być jak pięść”, co należy rozumieć: musi być zaciśnięta, zamknięta tylko w swoim gronie, niechętna zmianom. Fragment przywołuje także na myśl wyrażenie prawo pięści - 'bezprawie i przemoc panujące tam, gdzie można by się spodziewać pewnych norm postępowania, zwyczajowych lub prawnych' [ISJP II: 67-68]. W ostatnim przykładzie czasownikowi modalnemu towarzyszy frazeologizm ręka w rękę. Podkreśla on konieczność wzajemnego popierania się i współpracy nowej premier oraz prezydenta.

Wskazywaniu postaw i zachowań pozytywnie wartościowanych służy także czasownik powinien, który ma na celu wyrażanie rady. W książce Miało być odlotowo, czadowo, bojowo... Język i świat wartości czasopism szkolnych na tle pism młodzieżowych Marta Wrześniewska-Pietrzak [2012: 160] pisze, że tego typu konstrukcja ,,prócz modalności ukazuje też aksjologiczne zabarwienie wpisane w schemat 'Dobrze by było, gdybyś zrobił jakoś’”. W analizowanym materiale ten językowy środek wartościujący obecny był w wypowiedzi odnoszącej się do ewentualnego wykorzystywania przez Kopacz na scenie politycznej faktu bycia kobietą:

Pani premier kartą kobiecości powinna jednak grać ostrożnie, by nie pojawiło się wrażenie, że płeć jest nie atutem ale podpórką i prośbą o swoisty immunitet. [N 39: 2]

Przeanalizowany w niniejszym artykule wybór językowych środków wartościowania obecnych w tekstach prasowych poświęconych Ewie Kopacz obejmuje jedynie leksykę wartościującą. Już ten niewielki fragment zgromadzonego materiału dowodzi, jak wielka jest różnorodność sposobów wyrażania sądów oceniających. Wśród wyekscerpowanych na potrzeby niniejszej pracy jednostek leksykalnych znajdują się zarówno wyrazy prymarnie wartościujące, jak i opisowo-wartościujące. Są to przymiotniki, przysłówki, imiesłowy, zaimki oraz wykładniki modalności. Licznie reprezentowane są wypowiedzi, w których autorzy tekstów referują stwierdzenia wartościujące innych osób. Analizowane jednostki odwołują się przede wszystkim do kryterium utylitarnego, perfekcjonistycznego, poznawczego, społeczno-obyczajowego.

Wśród odnotowanych jednostek zdecydowaną większość stanowiły te z ujemnym znakiem wartości. Jak się okazało, zaangażowanie ideologiczne periodyków w niewielkim stopniu wpływało na obraz medialny Ewy Kopacz. W prasie konserwatywnej („,Do Rzeczy”, „W Sieci”, „Gazeta Polska”) obecne 
było niemal wyłącznie negatywne wartościowanie. Tygodniki, które określić można jako liberalne („Polityka”, „Newsweek”, „Wprost”, „Przegląd”, „Tygodnik Powszechny”), również wskazywały słabe strony nowej premier. Przywoływano w nich negatywne opinie na jej temat, ale często w bardziej zawoalowany sposób.

Językowy obraz Ewy Kopacz, jaki wyłania się z badanych artykułów, zawiera kilka konsekwentnie powtarzających się elementów. Polskiej premier przypisuje się emocjonalność, nieumiejętność panowania nad sobą, skłonność do niekontrolowanych wybuchów złości, co w efekcie daje obraz osoby histerycznej. Ponadto jest ona pokazywana jako jednostka niesamodzielna, która, co prawda, sporo osiągnęła, ale w większości dzięki kontaktom z prominentnymi osobami, w tym przede wszystkim ze swoim poprzednikiem, Donaldem Tuskiem. Na łamach prasy jest z nim nieustannie konfrontowana i porównywana. Wartościowane są ich relacje, sposób współpracy. Zestawiając te dwie postaci polskiej sceny politycznej, autorzy artykułów wskazują na dostrzegalne między nimi różnice charakterologiczne. Ewa Kopacz prezentuje się dużo mniej korzystnie niż Tusk, który zawsze, nawet w najtrudniejszych sytuacjach, emanuje spokojem i dobrze prezentuje się w mediach. Ona jest emocjonalna, łatwo można ją wyprowadzić z równowagi. Cieszy się dużo mniejszą sympatią polityków PO, którzy we wrześniu 2014 roku nie ukrywali swojego zaskoczenia propozycją kandydatury jej osoby na stanowisko premiera i wprost wyrażali obawę, czy nowa premier poradzi sobie z obowiązkami, jakie przejmuje.

\section{Spis skrótów}

$$
\begin{aligned}
& \text { DRZ - ,Do Rzeczy” } \\
& \text { GP - „Gazeta Polska” } \\
& \text { ISJP - Inny stownik języka polskiego } \\
& \text { N - „Newsweek” } \\
& \text { P - „Przegląd” } \\
& \text { PO - „Polityka” } \\
& \text { TP - „Tygodnik Powszechny” } \\
& \text { W - ,Wprost” } \\
& \text { WS - „W Sieci” }
\end{aligned}
$$




\section{Bibliografia}

\section{Źródta}

„Do Rzeczy” (2014), nr 36-40.

„Gazeta Polska” (2014), nr 36-39.

„Newsweek” (2014), nr 36-40.

„Polityka” (2014), nr 36-39.

„Przegląd” (2014), nr 36-40.

„Tygodnik Powszechny” (2014), nr 36-39.

„Wprost” (2014), nr 37-40.

„W Sieci” (2014), nr 36-40.

\section{Literatura}

Bańko Mirosław (2000), Inny słownik języka polskiego, t. I-II, PWN, Warszawa.

Bartmiński Jerzy (2003), Miejsce wartości w językowym obrazie świata, w: Język w kręgu wartości, red. Jerzy Bartmiński, Wydawnictwo UMCS, Lublin, s. 59-86.

Bartmiński Jerzy, red. (2006), Język. Wartości. Polityka. Zmiany rozumienia nazw wartości $w$ okresie transformacji ustrojowej $w$ Polsce. Raport z badań empirycznych, Wydawnictwo UMCS, Lublin.

Bauer Zbigniew (2010), Twój głos w Twoim domu: cztery typy tabloidyzacji, „Oblicza Komunikacji”, nr 3, s. 37-47.

Błachut Edyta (2014), O językowych sposobach referowania wartościowań, „Studia Linguistica", z. 33, s. 23-38.

Bralczyk Jerzy, Majkowska Grażyna (2000), Język mediów - perspektywa aksjologiczna, w: Język w mediach masowych, red. Jerzy Bralczyk i Katarzyna Mosiołek-Kłosińska, Upowszechnianie Nauki - Oświata „UN-O”, Warszawa, s. 43-50. Bugajski Marian (2010), Kultura tabloidów a język, „Oblicza Komunikacji”, nr 3, s. 68-73. Buława Monika (2014), Sposoby wyrażania sądów wartościujących w tekstach prasowych, Lexis, Kraków.

Cegieła Anna (2014), Stowa i ludzie. Wprowadzenie do etyki słowa, Elipsa, Warszawa. Dudek Antoni (2013), Historia polityczna Polski 1989-2012, Znak, Kraków.

Jarosz Maria, red. (2013), Polskie bieguny. Społeczeństwo w czasach kryzysu, Instytut Studiów Politycznych PAN, Warszawa.

Jędrzejko Ewa (2000), Modalność w języku $i$ w tekstach: od gramatyki do stylistyki, $\mathrm{w}$ : Kategorie pragmatyczne $w$ tekście literackim. Wstęp do stylistyki pragmatycz$n e j$, red. Ewa Sławkowa, Innowacje, Cieszyn, s. 113-155.

Kisiel Anna (2009), Wstęna analiza jednostki 'przede wszystkim' na tle właściwości ciagów nade wszystko i ponad wszystko, „Linguistica Copernicana”, nr 1, s. 93-109. 
Laskowska Elżbieta (1992), Wartościowanie w języku potocznym, Wydawnictwo Uczelniane WSP, Bydgoszcz.

Laskowska Elżbieta (1996), Typy wartości w tekstach potocznych, „Poznańskie Spotkania Językoznawcze", t. 1, s. 76-82.

Laskowski Roman (1977), Od czego 'lepszy'jest lepszy, „Język Polski”, z. 5, s. 323344.

Łapa Romana (2006), W sprawie wydzielania relacji modalności wyrażanej przez przyimki wtórne, ,Język Polski”, nr 1-2, s. 7-10.

Majkowska Grażyna (2001), Językowe sposoby aksjologizacji w dyskursie publicznym, w: Zmiany w publicznych zwyczajach językowych, red. Jerzy Bralczyk, Katarzyna Mosiołek-Kłosińska, Rada Języka Polskiego przy Prezydium PAN, Warszawa, s. $37-44$.

Majkowska Grażyna (2012), Język mediów w perspektywie aksjologicznej, w: Język w mediach. Antologia, red. Małgorzata Kita, Iwona Loewe, Wydawnictwo UŚ, Katowice, s. 39-52.

Majkowska Grażyna, Satkiewicz Halina (1999), Język w mediach, w: Polszczyzna 2000. Orędzie o stanie języka na przelomie tysiacleci, red. Walery Pisarek, Uniwersytet Jagielloński Ośrodek Badań Prasoznawczych, Kraków, s. 181-196.

Miluska Jolanta, red. (2012), Wartości w świecie polityki, Wydawnictwo Poznańskie, Poznań.

O Przegladzie (2016), http://www.tygodnikprzeglad.pl/o-przegladzie [dostęp: 16 kwietnia 2016].

Ożdżyński Jan (1999), Modalność i wartościowanie w dyskursie edukacyjnym, w: Wartościowanie w dyskursie edukacyjnym, red. Jan Ożdżyński, Sławomir Śniatkowski, Edukacja, Kraków, s. 89-104.

Ożóg Kazimierz (2004), Język w stużbie polityki: językowy ksztalt kampanii wyborczych, Wydawnictwo Uniwersytetu Rzeszowskiego, Rzeszów.

Piontek Dorota (2007), Tabloidyzacja dziennikarstwa, w: Polubić dziennikarstwo, red. Stanisław Zakrzewski, Wyższa Szkoła Nauk Humanistycznych i Dziennikarstwa, Poznań, s. 231-248.

Piontek Dorota, Hordecki Bartosz, Ossowski Szymon (2013), Tabloidyzacja dyskursu politycznego w polskich mediach, Wydawnictwo Naukowe Wydziału Nauk Politycznych i Dziennikarstwa UAM, Poznań.

Pisarek Walery (2008), Wstęp do nauki o komunikowaniu, Wydawnictwo Akademickie i Profesjonalne, Warszawa.

Puzynina Jadwiga (1984), O dyskursie oceniającym i dyrektywnym w tekstach prasy codziennej, „Poradnik Językowy”, z. 2, s. 69-78.

Puzynina Jadwiga (1992), Język wartości, PWN, Warszawa. 
Puzynina Jadwiga (2003), Wokót języka wartości, w: Język w kręgu wartości. Studia semantyczne, red. Jerzy Bartmiński, Wydawnictwo UMCS, Lublin, s. 19-34.

Puzynina Jadwiga (2004), Problemy wartościowania w języku i tekście, „Etnolingwistyka", s. 179-189.

Smolar Aleksander, Żukowski Tomasz (2011), Nie ma wojny polsko-polskiej. Dyskusja, „Więź”, nr 2-3, s. 91-102.

Smółkowa Teresa, red. (2013), Nowe słownictwo polskie. Materiały z prasy lat 20012005, cz. 3: $K-M$, Lexis, Kraków.

Szczepankowska Irena (2012), O semantyce zaimków, „Białostockie Archiwum Językowe", nr 12, s. 275-291.

Wrześniewska-Pietrzak Marta (2012), Miało być odlotowo, czadowo, bojowo... Język i świat wartości czasopism szkolnych na tle pism młodzieżowych, Wydawnictwo „Poznańskie Studia Polonistyczne”, Poznań.

Zuba Krzysztof (2012), Polska scena polityczna: ciagtość i zmiana, Wydawnictwo Sejmowe, Warszawa.

Magdalena Budzyńska-Łazarewicz

"The queen of chaos, emotionally disturbed, a hysteric that slams doors" a lexical way of evaluation in press articles dedicated to Ewa Kopacz (of chosen opinion weeklies from September of 2014)

Is to present lexical ways of evaluation, which are present in press articles dedicated to the election of E. Kopacz for prime minister. The study material consists of articles published in eight public opinion weeklies, which were published in Poland in September of 2014. They are journals with different ideological profiles. Among the noted lexical terms, there are primarily-evaluative as well as descriptively-evaluative expressions. These are adjectives, adverbs, participles, pronouns and modality indicators. Numerously represented are statements in which the authors report affirmations that evaluate other people. The analysed terms invoke, most of all, the utilitarian, perfectionist, cognitive, socially-custom criterion. Among the noted terms, the majority consists of those with a negative value mark. As it turned out, the ideological engagement of periodicals had a slight impact on the media image of E. Kopacz. An almost solely negative evaluation was present in conservative press. However, the press, which can be described as liberal, also pointed the weaknesses of the new prime minister, recalling negative opinions about her. It did it, however, in a more veiled manner.

Keywords: lexis; Ewa Kopacz; evaluation; the press; opinion weekly. 
mgr Magdalena Budzyńska-Lazarewicz - doktorantka w Zakładzie Gramatyki Współczesnego Języka Polskiego i Onomastyki w Instytucie Filologii Polskiej Uniwersytetu im. Adama Mickiewicza w Poznaniu, pracownik Biblioteki Raczyńnkich; zainteresowania naukowe: wartościowanie kobiety w polskich tygodnikach opinii, etyka języka, biblioterapia. 